CIHM

Microfiche Series (Monographs)
ICMH

Collection de microfiches (monographies)

Cenadien Institute for Historical Microreproductions / Institut canadien de microreproductions historiques
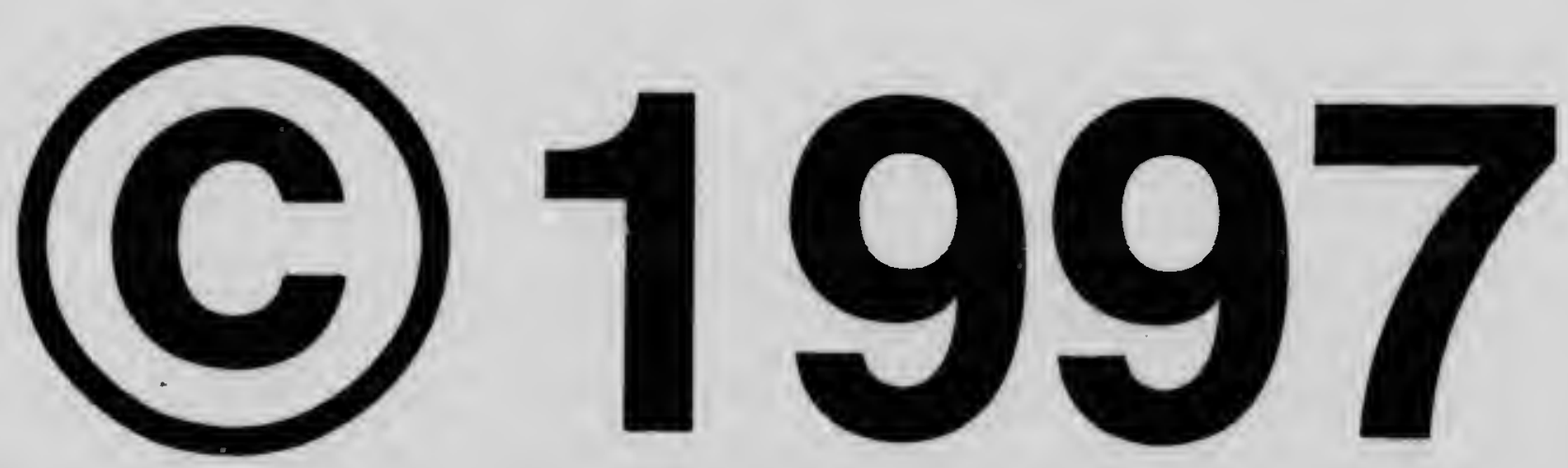
The copy fiimed here has been reproduced thanks to the generosity of:

Librery
Agriculture Canada

The imoges eppearing here are the best quality possible consldering the conditlon and iegiblitity of the originel copy and In keeplng with the filming contract speciflcetions.

Jriginol copies In printed peper covers are filmed beginning with the front cover and ending on the lest page with e printed or liiustreted Impres. sion, or the beck cover when approprlote. All other originel copies are flimed beginning on the first pege with a printed or lilustrated impres. sion, and ending on the lest page with a printed or lliustreted Impresslon.

The leat recorded frome on each microflche sheil contain the symbol $\rightarrow$ Imeaning "CON. TINUED"). or tha symbol $\nabla$ (moaning "END"). whichever eppiles.

Mops, plates, cherts, otc.. may be filmed at different reduction rotlos. Those too lerge to be entIroly Included In one exposure are fllmed beginning in the upper loft hand corner, loft to right and top to bottom, os mony fremes as required. The foilowing dlagrams Illustrate the mothod:
L'exemplaire filmb fut reproduit grsce a la generosite de:

Bibliothique

Agriculture Cenade

Les imeges suivantes ont stó reproduites avec ie pius grand soln, compte tenu de ie condition et de le netroté de i'exempialre flimb, ot on conformito evec les conditions du contrat de fllmege.

Les exempieires orlglnaux dont ie couverture en popler cat imprlmbe ront fiimbs en commençent por le premier piat et en torminant soit par is derniôre pege qul comporte une empreinte d'Impresslon ou d'iliustratlon, soit par ie second plot, selon ie ces. Tous les autres exempielres originaux sont filmés en commençant per la premilre page qul comporte une emprointe d'Impression ou d'iliustration et en terminant per ie dernläre page qul comporte une telie emprointe.

Un des symboles sulvants epparaitra sur lo dernlóre Imege de chaque mlerofiche, selon le cas: ie symbole $\longrightarrow$ slonifle "A SUIVRE", io symbole $\nabla$ slgnifle "FiN".

Les cartes, plenches, tabloaux, otc.. peuvent etro filmbs a dos taux de róductlon difforents. Lorsque lo document est trop grend pour stre reprodult en un seul cilcho. II est filmo i pertir de leangle suplrleur gauche, de geuche droite. ot do haut en bes, en prenant ie nombre d'Images nócessalre. Les diegremmes suivanta Iliustrent ia methode.
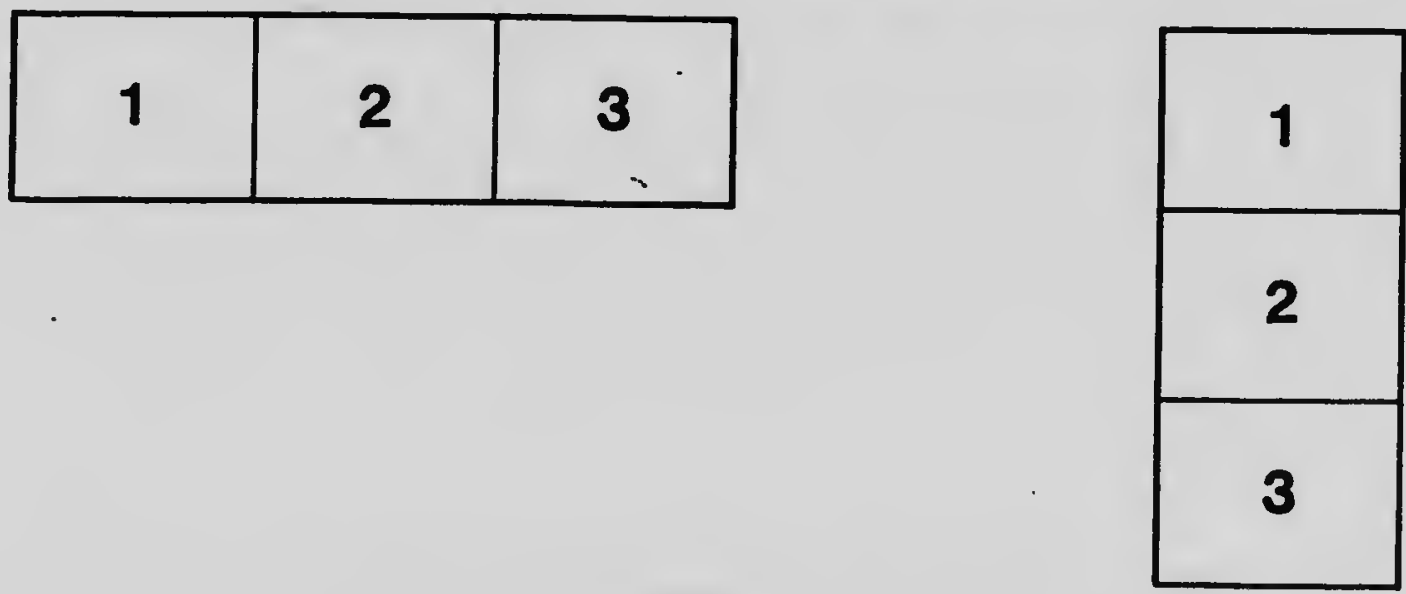

\begin{tabular}{|l|l|l|}
\hline 1 & 2 & 3 \\
\hline 4 & 5 & 6 \\
\hline
\end{tabular}




\section{Technical and Bibliographic Notes / Notes techniques et bibliographiques}

The Institute has attempted to obtain the best original copy available for filming. Features of this copy which may be bibllographlcally unique, which may alter any of the images In the reproduction, or whlch may slgnificantly change the usual method of fllming are checked below.

\section{$\square$}

Coloured covers /

Couverture de couleur

Covers damaged /

Couverture endommagée

Covers restored and/or laminated /

Couverture restaurée etlou pelliculée

Cover tille missing / Le titre de couverture manque

Coloured maps / Cartes géographiques en couleur

Coloured Ink (l.e. other than blue or black) /

Encre de couleur (i.e. autre que bleue ou noire)

Coloured plates and/or illustrations /

Planches et/ou Illustrations en couleur

Bound with other material /

Relié avec d'autres documents

Only edition available /

Seule édition disponible

Tight binding may cause shadows or distortlon along Interior margin / La reliure serrée peut causer de l'ombre ou de la distorsion le long de la marge intérieure.

Blank leaves added during restorations may appear within the text. Whenever possible, these have been omitted from filming / II se peut que certaines pages blanches ajoutées lors d'une restauration apparaissent dans le texte, mals, lorsque cela était possible, ces pages n'ont pas été filmées.
L'instlitut a microflime le melijeur exemplaire qu'll lul a été possible de se procurer. Les détalls de cet exemplaire qul sont peut-etre uniques du polnt de vue blbliographique, qui peuvent modifler une Image reproduite, ou qul peuvent exiger une modification dans la methode normaie de filmage sont indlqués cl-dessous.

\section{Coloured pages / Pages de couleur}

\section{Pages damaged / Pages endommagées}

Pages restored and/or laminated I

Pages restaurées etou pelliculées

Pages discoloured, stained or foxed /

Pages décolorées, tachetées ou plquées

Pages detached / Pages détachées

\section{Showthrough / Transparence}

Quality of print varies I

Qualité inégale de limpression

Includes supplementary material /

Comprend du matériel supplémentaire

Pages wholly or partially obscured by errata slips, tissues, etc., have been refilmed to ensure the best possible Image / Les pages totalement ou partiellement obscurcies par un feuillet d'errata, une pelure, etc., ont été filmées à nouveau de façon à obtenir la meilleure Image possible.

Opposing pages with varying colouration or discolourations are filmed twice to ensure the best possible image / Les pages s'opposant ayant des colorations variables ou des décolorations sont filmées deux fois afin d'obtenir la meilleure image possible.

\section{Additional comments /}

Commentaires supplémentaires:

Pagination is as follows: p. [2], [217]-228.

This hem is filmed at the reduction ratio checked bolow I

Ce document est filmb eu bux de reduction indiquil ch-iseove.

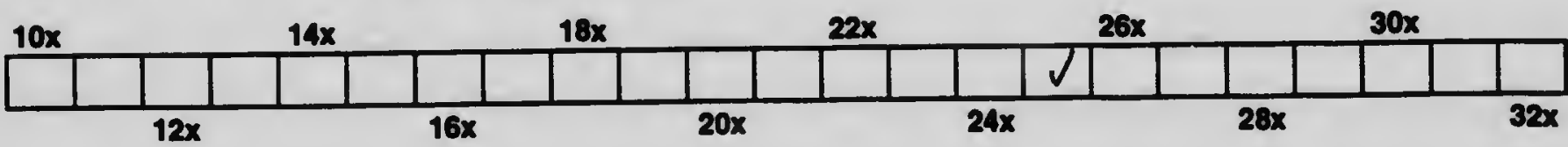




\section{Microcont Rscution TEST CAART}

(ANSI and ISO TEST CWART No. 2)
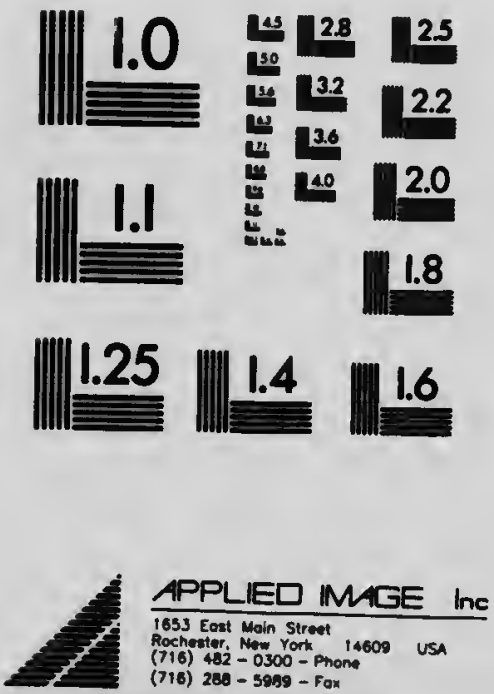


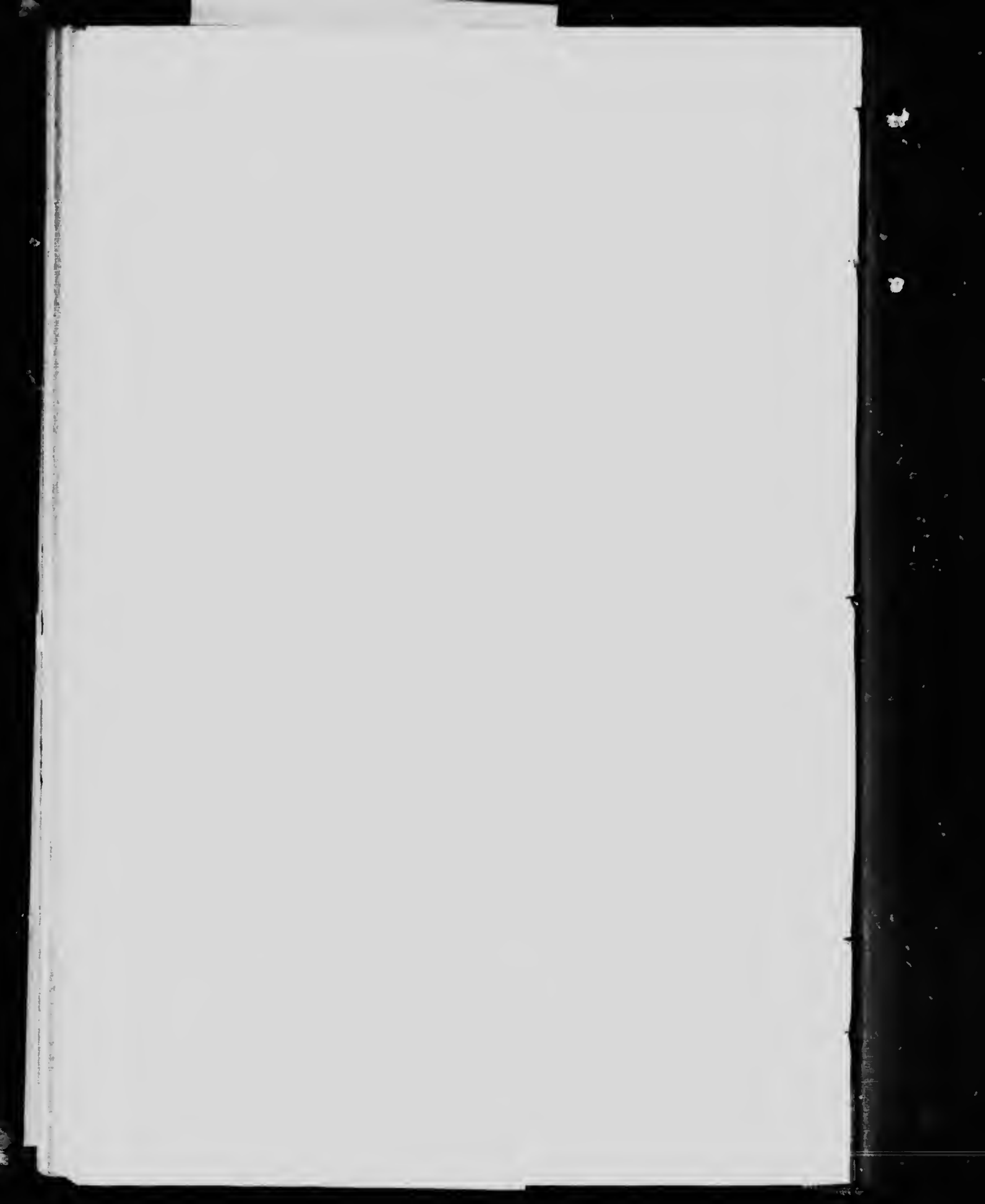




\title{
BACTERIAL DESTRUCTION OF COPEPODS OCCURRING IN MARINE PLANKTON.
}

\author{
By WHFRID SADLER, X.Sc., B.S.A., \\ Bacteriological Iabsratories, Madonald College (MoGill Univenity), Province of \\ Quebec, Canada.
}

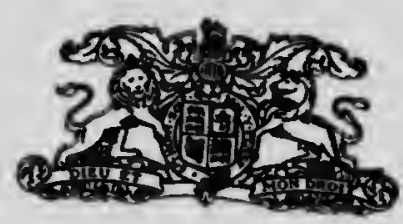

OTTAWA 


\section{XIII.}

\section{BACTERIAT DESTBUCTION OF COPEPODS OCCURBTTO IM YARINE PLANTTOR.}

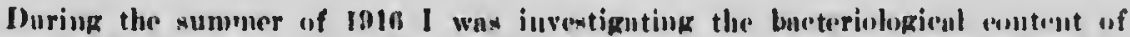

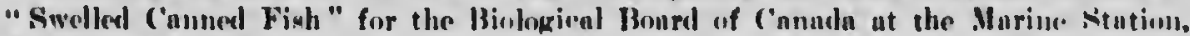
Nt. Audrew: X.B.

While there Dr. Arthur Willey (I'rofogsor of Zorology, Me(iill I'nivereity) inllel

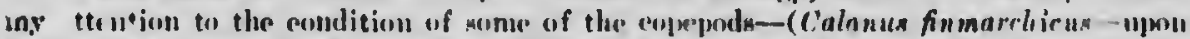

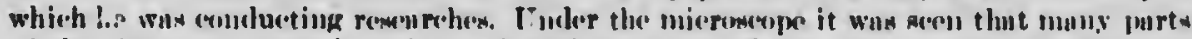

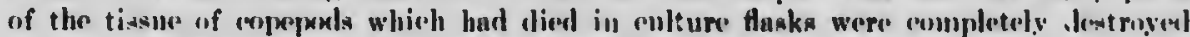
ly maxses of what appearesl to ho bucteria. It was particularly untipenl that the nsial cavity in the first antemuae was entirely oreupied by a dense column of writhiug organ-

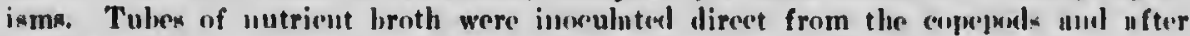

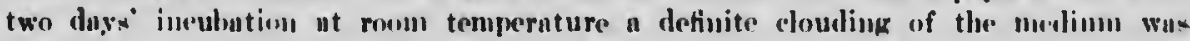
notml.

At the rejuest and on the sukgestion of Dr. Willey I hove procenderl with the

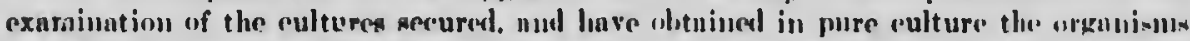
eoneerued. Three sperifie strolus of burtoria huve been isolated.

Inusmuch as the work muy huse some prometionl vimuifienuer in rolations to the. meneral suljeret of marine binlogy, nud is of seientifie interest, this report of the

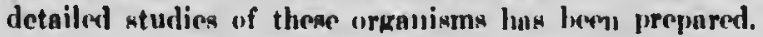

\section{MFDIA F.MPLOYED.}

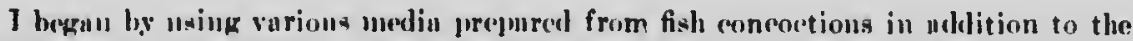
ordinary laburntery umdia. The latter, however, proved to be more sntisfnetory in every wuy aud I have therefore "ontined nusolf to their use entirely.

Bef Peptone Agar.-Standarl methols' - Borf extrapt lecing substitu יd for iment.

Beef Peptone Gelatine.-Stunduril mothurk.'

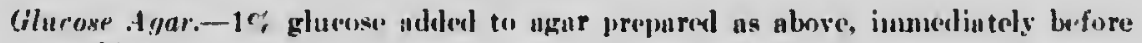
tubink.

Sodium Indigo Sulphate Agar:-3 per mot. sodimu indigo sulphate with per resit. gheoso ndderl to ueutral newr. tuberl and sterilized in flowing str an for three sureessive days.

Tochtermann's Serum Ayan.-" For digestion towt.

Lïeffler: Blond s'surum.-_.

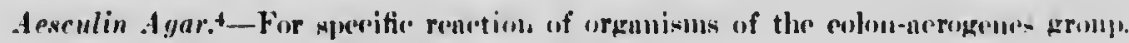
laopse of a broth inlture spreatl on plates.

. Teutral Red Bilo salt Agar."-Ditto, ditto.

Bouillon for logye-Proskauer reartion, ${ }^{6}$

Bonillaw for the .Hethyl Red Reartion.7-

Solution for reduction of Nitrates to Nitrites.-(riltuy's șynthetic solution was nsed, sud ulso a peptone potussium-nitrate solution.

$2: 336 ;:-13 \mathrm{t}$. 
Dunham solution for Indol Production,-1 per eene peptone, of per cent NaCr dimolred in distilled water, the renction adjunted $: 0+10$. mellum eleared with white of exs, Altered, tuberl and aterilized. After 7 days' ineubation at $37 f^{\circ} \mathrm{C}$. the cultures were tosted for indal by the Bohme Bhrlich test ${ }^{\circ}$; the development of a rherry red colour iudientius the premence of indal.

Fermentation brotho. - The variou* wuxap: alconholm, pluensiden uad were prepured separately as to per ment molutions in dintilled inter, and sterilizal for 15 minutes in Howing stenin for three successive day. Immerlintely before inoculation these were addied to tules of broth made up as for the iudol teatthe use of peptusic water without heef eliminaten any riak of the reaction beiug makked by nction on the muncle suxar-in such proportions an to give a flual 1 per ceist sugar of other carbohydrate broth. Dunhani tubes were used for the collection of the ma. For acid produrtion the acid fuchnin indicator of Andrade," as ndapterl by IIollman, was umer at the rate of 2 per cent.

In the preparation of the indicator I liave notiend an reportar by Andradr, and Ilollman that the colour wlich results from the addition of the liormal caustic soda is preverptibiy uffecterl by being left upen to the air. By adding the chn atic madu to frewhly propared noid fuchsin solution at iutorvals throughout the day, leaving the reagent meanwhile exposed to the air, I have found that 21 e. $11 / \mathrm{NuOll}$ will derolorizo to the proper shade of ninber $100 \mathrm{ec}$ fuchsin solution.

Litmus Milk:-Tlie milk froshly sepwruted und tubed was sterilizel for three suecessive days for 30 minuter in flowing steam. The litmus was made up separately: " T per cent solution of "Merck's" litmus in distilled water, hented in the steamer for 30 minutes and loft over night in the incubntor, f.ltered, stcrilized for three suecessive days in flowing stenm and added to the milk immediately before inoculation it the rate of 1 per eent.

Notr: It will be sevil from pare 224 that culture 111 of this paper exhibited an unusual degrec of seusitiveuess to the litmus. For this reason 1 now consides the proportion of the indieutor added to be of some importanee

\section{CIIITERAI, STLDIES.}

\section{Culture I.}

Marphotogy--Microscopieally-24-hour-old agar culture at $37^{\circ} \mathrm{C}$ - - short rods varying up to $1-11 \mu$ long and $1 \mu$ loroud; nonc larger forms; stuins unevenly witl Kuhwe's uethrlene blue, and is (iram negative. No spores are forn.exl and no capsule showil.

Motility.-Decided browuiun movement, lmt unt the violent apitation noted in culturc

1II. No motility.

Ciultural Characteristics:-

Agar Slope.-24 hours at $37^{\circ} \mathrm{C}$. growth luxuriant, ruisenl, slightly sqreading, poist slistening, porceluin-white, edgrs echinulate.

Gluc. Jar Slope.-Gas, growth luxuriant, raised, moist, glistening, woolly appeu rance, loaze, porcelu ilı-white, spreading.

Tochtermann's Serum Agar Slope.-Resembling growth on glucase agar, but no woolly apperarauce. In 8 days growtl lad pormeated medium as Hakes; gas, heavy precipitate eollectrd at base of slope.

Löeffler's Blood Sprum.-Modernte, spreading. flat, no digestion, no discolouration. In 7 days no digestion; colour isabella, luxuriant, moist, slightly raised, iridiseent. 
sesional pApER No. so

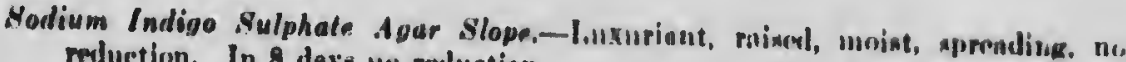
reduction. In 8 dayin mo miluction.

Delatine Nlab. $-21^{\circ} \mathrm{C}$. 24 hourn, expowth flifom, mual surface aul stab. Iu " duy as before; ans bubblew-prewumably from the musele sugar in the herf pat ract

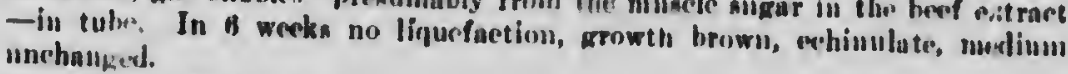

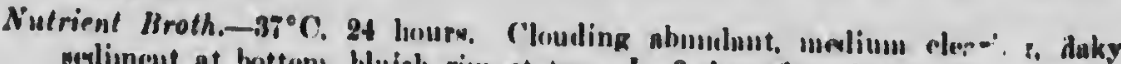
malisnont at bottom, bluish rim at top. In 1 doys floceulent redo. ali-whing? rini at top, enaily dialomkerl ou whakiug. Modiun aluost relenr.

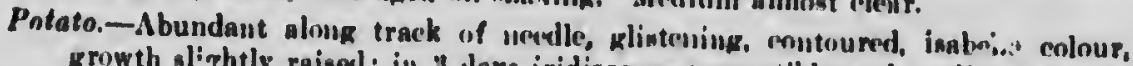

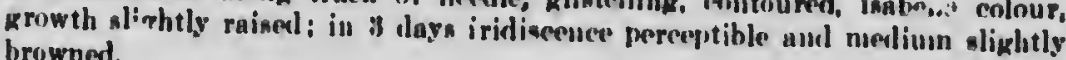
browned.

Milk:-Comgulation in 24 to 30 lonrx; curd broken ly kn s bubblew. In 6 weeks eurd contraeterl, nn aligestion

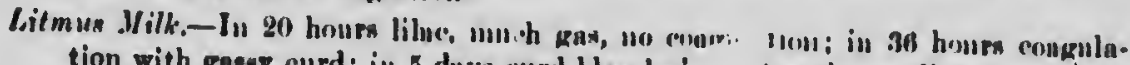

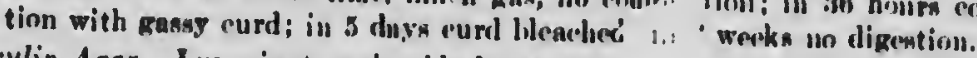

A earulin Agar.-Luxuriant, moixt, blark reaction

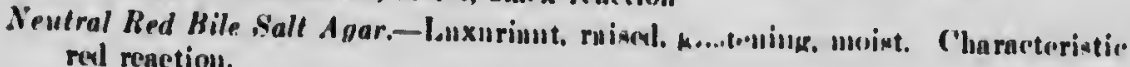
rel reaction.

Peptone Broth + A earulin,-Blark revretion.

Gelaline Colonies.-(1st appearance) 5 days at $21^{\circ} \mathrm{C}$. Surfuce colonies up to $1 \mathrm{~nm}$. dianeter, raimed, wlikhtly darker in rentro, paliug town rla eriges. Puler the low power objertive homogenous, kramular. elpew eutire.

Agar Colonies,-2t hours at $37^{\circ} \mathrm{C}$. Surface coloniew up to 3 inm. diameter, rainel. concuve, alistening, vollowish-white at centre, paling towards erlges, erlges

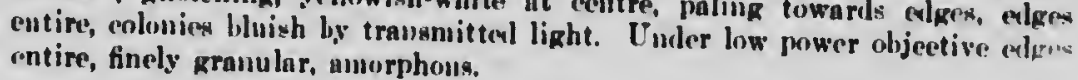

Temperature Kelations:-

Thermal Death Point.-10 nus. exposure in untrient broth at $60^{\circ} \mathrm{C}$. Optimum Temperature. $-37^{\circ} \mathrm{C}$. Cultures incubatel at $37^{\circ}, 21^{\circ}$, and $14^{\circ} \mathrm{C}$. respec.
tively.

Vilality on Cullure Media ..etivin cultures hive Inem rescored from agar after 5 months at temperutus. $: 13^{\circ}-31^{\circ} \mathrm{C}$.

Relation to Oxygev.-Faruliutive anacrobe: mlueose ugar.

Biochemical reactions :-...

Indo: piduction: Init produced.

Redu. : . of nitruter. Nitrates rorlurerl to nitrites.

Voges-l'ruskauer redction: Negative.

Methyl red reaction. Aril.

Eermentation of Carbohydrates:-

Glucose. Lactose. Saceharose, Maltose. Mnnnite. Duleite.

Dextrine.
++ $++$ $+$

Saliciu.

$++$

Raftinosc.

$++$

Glyeerime. $++$

$+=$ acid.

$++=$ acid and gas. 
Culturally and biochemieally this organism is a variation of the $B$. coli type "ccording to the deseription of Escherieh.1" The variety I have isolated differs from the origina: description in that it is non-motile and ferments saccharose to acid and gas. The degree of importance to be attached to any one charueter lias beell diseussel at considerable length in the literature during the last thirty years; owing to the faet that this organism is used as a presumptive test for faecal contamination in systematic water analysis. Of the two variations from the original type mentioned above, the presence or absenee of motility may first be cousidered.

There las been a tendeney by some workers to consider a non-motile form of $\boldsymbol{B}$. coli (Escherieh) ${ }^{10}$ as $B$, aerogenes (Eseherich) ${ }^{11}$. This position, however, is not substantiated by the researches of Escherieh and Pfaundler, MaeConker, Juckson and other. Feherieh and Pfaundler'z in cleseribing the original $B$. coli state that generally there is motility, sometimes slight; a elaracteristie novement as of short forward pushes: swinking in spaee with sometimes no change of place is ulso noted. The absenee of definite motion as recorded by Tafel, Frankel and others is eited in the sume puper. Lembke ${ }^{13}$ considers that inotility in $B$. coli is variahle. McWeeney't in diseussing what he would regard as the genuine $B$. coli remarks: "on the motility of individuals or its absence I hesitate to lay much stress." Houston'1" in using a broad elassitieation for the true colon group udopts his "flaginac" test which leaves open the question of motility. Durham ${ }^{16}$ considers that all members of the true colon group are probably motile; but in the sune paper states: "speaking generally inorpholopical charaeters are not of much value for subdivision of these baeteria."

I acConkey ${ }^{17}$ diseusses the influence of temperature and medium on motility; and while he considers the presenee or absence as importunt he says: "it is very difficult to arrive "It " conclusion with regard to this claracter." Ellis ${ }^{18}$ has proved the presenee of flagella in five species of the genus Bacterium which were hitherto held to be nonmotile; and he eonsiders that all the genus Bacterium when suitably cultivited ean be shown to be motile. His eonelusions would appenr to be not kufficiently suhstantinted on the datu given. The English Comnission on the Standarlization of Methods for the bacteriological exanination of water ${ }^{10}$; und the American Commission ou Stundard Methmis each specify motility as one charncteristie of the true $B$. coli: but a connparisul of the two staudards reveals variance as to the siguificance to $h$ attaehed to this sperifie feature. Prescott and Winslow ${ }^{20}$ consider the sugar fermentations, particularly the fermentations of glucose und lactose, are of prime importance. Suvager21 considers motility as one of the essential characters of the true $B$. corli. Miguln": includes $B$. neapolitanus (Emmerieh) ${ }^{2 a}$ which is non-motile, as identical with $B$. coli (Escherieh).

Thus while the concensus of opin on is undoubtedly in favour of specifying motility as a character of the true $B$. coli, there would seem to be no justifieation nceordiug to present classifiention for excluding from this type an organism preponderatiugly similar and plaeing it with $B$, (progenes (Escherich)" ${ }^{11}$ on account solely of the abrence of motility. IIarrison:" raises the question as to whether, provided the argmment $r$ motility is admitted, it removes $B$. neapolitanus to a different genus from B. coli.

The seroud variation to which I have referred (page 219) is the formentation of saechurose to aeid and gas. $B$. coli (Escherich) ${ }^{10}$ has no netion upon saccharose. Theobuld Snith, eited hy Preseott and Wiuslow 20 stated in 1893 that B. coli eould be diviled into two distinct sub-types, - the one negative to saccharose or in other words the original $B$. coli, und the other fermenting this sugar'to acid and gas. Durham ${ }^{16}$ isolated saceharose-positive onganisıns and gave the name $k$. coli communior, since coutrueterl to $B$. communior. Jueksou"t lus classificd the organisms of the laetose fermenting type and confirms the sub-type $B$. communior of Durham. The classifieation of Jackson has since been udopted by the laboratory section of the Ameriean Publie IIealth Assoeiation, ${ }^{1}$ and on this continent has received almost general approval. Ising saccharuse and dulcite as differential fermentation tests. Jacksum eonsiders 


\section{SESSIONAL PAPER No. 38.}

those organisms positive to lactose and dulcite as $B$. coli (Escherich) ${ }^{10}$; posit:ve to lactose, saccharose and dulcite as $B$. communior (Durham) ${ }^{10}$; positive t: lactose and saceharose but negative to dulcite as $B$. arrogenes (Escherich)", positive to lactose but negative to saceharose and dulcite as $B$. acidi-lactici.24 Further subdivision aceording to the action on manuite and raffinose are used for further differentiation.

MaeConkey uses the Voges-Proskauer reaction as one of his differential tests and finds that the true $B$, coli is always Voges-Proskauer negative, while the $B$. cerogenes y!ge is Voge. Prrskaucr positive. In the same paper le revives ihs nime $B$. n-spolitanus (Emmerich) ${ }^{23}$ and uses this nomenclature for his saccharose positive dulcite positive strains instead of the name given by Durhain- $B$. cumm s:ser. Mar.'onkey obtained a pure culture labelled $B$. neapolitanus from Kral, and out of 480 coli-like organisms isoluted from human and animal faces he found that 23 per cent gave bio"hemieal reactions identical with the Kral culture used by hin as control. II, states that le ennnot agree with Migula in describing $B$. neapolitanus (Emmerich) as identical with $B$. coli (Escherich). As, however, the differentiation by means of carboliydrates other than glueose and lactose has been amplified since the classification by Migula, the conclusions of both Migula and MacConkey on this particular point are fierfectly legitimate. Jordan ${ }^{25}$, in designating the saceharose-positiv s dulcite-p psitive group uses $B$. communior and $B$. neapolitanus interchangeably; biochemically this as correct, but the former is motile (16), the latter non-motile ${ }^{23}$. Levine ${ }^{26}$ who apparcntly follows MacConkey has lately studied 333 strains of lactose fermenting bacteria from various sources. He goes one step further and giving $B$. neopolitanus its original character of non-motility according to Enmerich ${ }^{23}$, uses that nomellrlature to include non-motile forms of $B$. communior (Durhain). To say the least it is interesting to revive $B$. neapolitanus as a sub-type of $B$. coli (Escherich) in view of the following statement by Jordan ${ }^{25 a}$ : "According to a strict application of the rules of priority, the hacillus now kuown as $B$. coli should be ealled $B$. neapolitanus." The dutes of the original publication by Emmerich ${ }^{23 a}$, and Fscherich ${ }^{10}$, of course bear out
Jordun's statement.

Howerer, aceording to the first descriptions of Emmerich ${ }^{23}$ and Escherich ${ }^{10}$ the former found a non-motile strain and the latter a motile strain of a lactose fermenting organism. Later work already referred to has separated these two strains on the basis of sacchinrose fermentation ${ }^{28}$. We thus have two features in which the respective strains differ. A propos of the stand taken by Durham and MeConkey, Harrisones opens the question as to whether it is legitimate to nanc ns a species, an organism
differing only in the fermenting of one sugar.

It would therefore seem legitimate, on the ground of present day classifiention, to tentaticly charucterize the organism I lave isolated-a non-motile. lactose, saccharose, duleite positive, Voges-Proskauer negative strain,-as a variety of the sub-type. $B$. neapolitanus of the classic $B$. coli type of Escherich. To use $B$. neapolitanus conflicts with the nomenclature $B$. communior more usually accepted for the strains giving identical rcactions. If motility is considered, $B$. neapolitanus and $B$. communior are not strictly the same; but to nse the single characteristic, absence or presence of motility. to separate $B$. communior and $B$. neapolitanus, and at the same time to say thut a $n$ nn-motile form of colon is identical with a motile form may seem ineonsistent.

The difficulty can be overcome by the tentative elassification of the organisin I lave isolnted as non-motile strain of the sub-type $B$. communior (Durham) of the type $B$. coli (Escherich): or to take the differentation further, as $B$. neapolitanus, a sub-type of $B$. roli (Escherich).

\section{Culture II.}

Morphology.-Microseopieally-2t-hours-old agar culture at $37^{\circ} \mathrm{C}$--rods rarying up to $1.6 \mu$ long and $.8 \mu$ hroad; some not much longer than brond; stains evenly with Kühne's methylenc blue and is Grun negutive. No spores; no capsules have
lecn demonstrated. 
Motility.-Rapid movement, darting to and fro, many revolve as on an axis.

Cultural Characteristics:

Agar Slope. -24 hours at $37^{\circ} \mathrm{C}$--moderate, bluish by transmitted light, moist, glistening, slightly raised, later becoming by transmitted light yellowish in centre gradually merging into transparency.

Glucose Agar Slope.-Gas, growth moderate to luxuriant, glistening, slightly raised.

Tochtermann's Serum Agar Slope.-Moist, slightly raised, bluish by transmitted light, spreading discrete colonies, gas. In 8 days growth had become yellow, much water of condensation, heavy greyish-white precipitate at base of slope.

Löeffler's Blood Serum.-Moderate, filiform, moist, glistening, no liquefaction, no discolouration. In 7 days no digestion, no discolouration.

Sodium Sulphate Agar Slope.-Raised, spreading. moist, no reduction. In 8 days no reduction.

Gelatine Stab. $-21^{\circ} \mathrm{C} ., 24$ hours, growth filiform, equal surface and stab; 7 days, tendency to echinulate. In 6 weeks no liquefaction, growth yellowish-brown; characteristic lateral growths resembling a poplar tree againgt the horizon; medium unchanged.

Nutrient Broth. $-37^{\circ} \mathrm{C} .24$ hours. Clouding abundant, no pellicle, no sediment, bluish rim at top. In 1 week, slight sediment; otherwise no change.

Potato.-Moderate, flat, yellowish-white along track of needle.

Milk.-In 6 weeks no change.

Litmus Milk.-Varies fron 10 change to a tint slightly more alkaline than control; blue rim at top.

A esculin Agar.-Black reaction, growth less luxuriant than in Culture I.

Neutral Red Bilesalt Agar. Moderate, pink reaction.

Peptone Broth + Aesculin.-Black reaction.

Gelatine Colonies.-5 days at $21^{\circ} \mathrm{C}$.-colonies up to $5 \mathrm{~mm}$. diameter; under low power objective granular; edges lobular to contoured, sentre dark with paling towards edges. Deep surface colonies granular eentre with dark concentric rings.

A gar Colonies. -24 hours at $37^{\circ} \mathrm{C}$.- - surface $1 \mathrm{~mm}$. diameter, raised, concave, bluish by transmitted light, round, smooth, edges entire. Under low power objective granular, edges entire.

Temperature Relations:-

Thermal death point: 10 minutes exposure in nutricut broth at $55^{\circ} \mathrm{C}$.

Optimum temperature: $37^{\circ} \mathrm{C}$; cultures incubatel at $37^{\circ} \mathrm{C}, 21^{\circ} \mathrm{C}$. and $14^{\circ} \mathrm{C}$. respectively.

Vitality on Culture Media:-

Active cultures have been recovered from agar tubes after 5 months at temperature of $15^{\circ}-20^{\circ} \mathrm{C}$.

Relation to Oxygen:-

Facultative anaerobe; glucose agar.

Biochemical reactions:-

Indol production: Indol not produced.

Reduction of nitrates: Nitrates reduced to nitrites.

Voges-Proskauer reaction: Positive, after 6 hours.

Methyl red reaction: Faint acidity, shortly followed by reversion to alkalinity. 


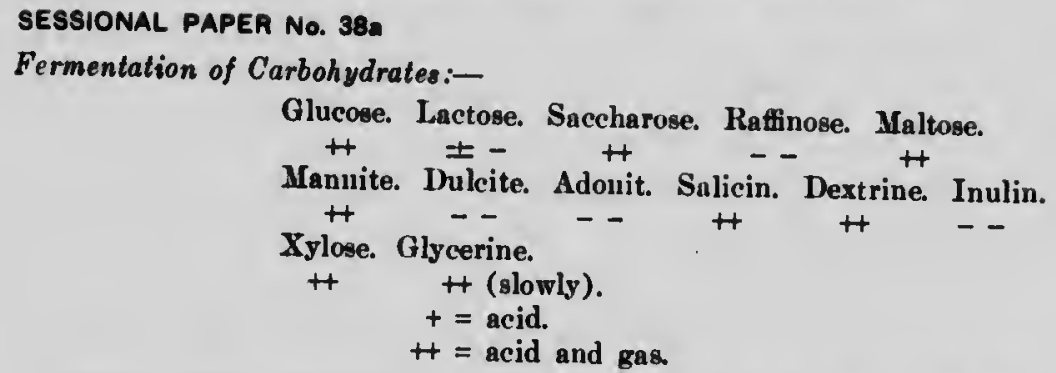

Nore. - The fermentation of lactose to acid is faint, and in two days reduction
is noted.

The classification of this culture must be purely tentative. It will be seen that while saccharose, maltose, mannite, salicin and dextrin are fermented to acid and gas, the organism fails to ferment lactose to gas and only faintly to acid. This has persistently been the case through several mouths; on one occasion, however, a small lubble of gas-1 mm. diameter-appeared in a Durham tube. This I have been unable to obtain since, confirming in triplicate. MacConkey states: "It has been my experience that where an organism produces acid and gas in onc medium and apparently only acid in another, under proper subcultivation the organism will produce gas in the second medium."17 Harrison in this laboratory has frequently cited to me verbally his own experience in this matter, which bears out the statement of NacConkey. While the organism is definitcly motile it differs from $B$. cloacae of Jordan $^{20}$ in that it fails after three months to liquefy gelatine, fails to ferment lactose to gas, and fails to coagulate milk after several weeks. Rogers Clarke and Evans $^{30}$ found that the group of the types they isolated from grains-Group Bfermented to acid and gas glucose, saccharose, mannite, glycerine and adonit, but like my culture failed to ferment lactosc; on the other hand this group liquefied

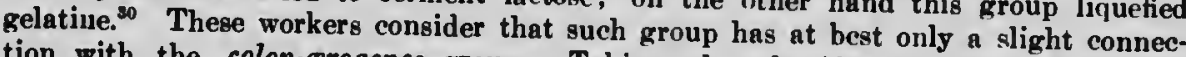
tion with the colon-arogenes group. Taking the classification adopted by the American Public Health Association ' the culture would be ruled out of the colon-cerogenes group at once on account of its failure to produce gas trom lactose; further, milk is not coagulated. Certain of the biochemical reaetions would tend to suggest the Gaertner group. According to Besson ${ }^{31}$ the organisms of this group are negative to otose, saccharose, salicin, raffinose and inulin; while those carbohydrates to which the group is positive ilclude dulcite. This organism, it will be noted, is negative to dulcite, lactose and inulin but positive to saccharose and salicin. Jordan ${ }^{32}$ in a study of 74 strains of the $\mathrm{Ga}$ :rtner group cites that the reaction to dulcite and xylose is variable, but includes dextriuc among the fermentable substances not attacked; thus cstablishing at once a similarity and a variation respectively as compared with the organism lere described. In the same paper Jordan describes strains where reaction to litmus nilk cannot be differentiated from the control. Savage ${ }^{33}$ in a elassification of the Gaertner group divides such into two
sub-groups:-

a. True-Gaertner bacilli;

b. Para-Gaertner bacilli;

to which he had previously drawn attention in reports to the Local Government Board, 1906-7-8. Citing from Savage: "The bacilli of the para-Gaertner sub-group are a number of organisms, for the most part unnamed, which appear to be not very uncommon in the healthy animal and human intestine, and which are of chief interest from their elose resemblance to true-Gaertner bacilli. . . . They can only be culturally differentiated from the true-Gaertner organisms by an extended scries of fermentation tests while they fail to be agglutinited by immunizing animals with 
8 GEORGE $V, A .1918$

any of the members of the true-Gaertner sub-group. They are also for the most part non-pathogenic. They have not 80 far been found as a cause of disease in man or in animals."

Until I am able to secure for comparative cultural tests strains of this sub-group from Dr. Savage, it would not be wise to attempt a more definitc classification of the organism herein discussed. In view, however, of the decided variation from the Voges-Proskauer type of the colon-cerogenes mroup as lately given by Levine, ${ }^{20}$ and considering the many cultural features and fermentative reactions which suggest at any rate a distant relationship to the para-Gaertner aroup, it seems not undesirable to suggest that based on the cultural features and biochemical reactions this organism be considered tentatively as an atypical form of the para-Gaertner group according to Savage. ${ }^{.3}$

Culture III.

Morphology.-Microscopically the organism appeurs as a coceus, in pairs, in masses, and as short streptococci; the average diameter, from a 24 -hour-old agar culture at $37^{\circ} \mathrm{C}$. being $.8 \mu$, stained with Kühne's methylene blue. The organism is Gram positive and non-spore-forming; capsules fuintly disceruible.

Motility.-Tests for motility made in hanging drop of condensation water from 2 young agar culture. No motility. Violent agitation ean be noticed, and rotation of the eells as on an axis, but the position in the drop is unchanged.

Cultural Characteristics:-

Agar Slope.-24 hours at $37^{\circ} \mathrm{C}$. growth scanty, bluish bx transmitted light, filiform, flat, with later a tendency to spreading.

Glucose Agar Slope.-Growth moderate, heavicr than on agar, discrete colonies, flat, spreading. glistening.

Tochtermann's Serum Agar Slope,-Growth seant to moderate, bluish by transmitted light, heavy clouding of the condensation water. In 5 days slight digestion of the medium noted.

Löeffler's Blood Serum.-Growth filiform, medium channelled and slightly darker in colour. In 5 days growth glistening, yellowish, slight digestion.

Sodium Indigo Sulphate Agar Slope.-Faint growtl, no reduetion of colcur, 24 hours. In 14 days reduced to reddish brown.

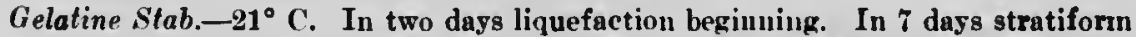
liquefaction for $\$$ of tube, even elouding with yellowish floceulent precipitate at bottom. Liquefaction complete in 1 month.

Nutrient Broth. $-37^{\circ} \mathrm{C}$. even elouding, moderute, no pellicle, no sediment; later mediun eleared.

Potato.-Barcly discemible growth in 24 linurs. In 3 days faint growth, flat, spreading, white, metallic lustre.

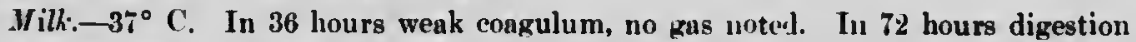
had begun, a clear lemon coloured liquid extending for 1 tube. In 7 days tube half fluid, curd soft, gelatinous, bright and of a solidity resembling macaroni; casily desintegrated on shaking; after 2 inouths some curd still remaining, lemon yellow in colour, consistency as hefore.

Litmus milk.-The reaction of the organism to this medium is unusual, and it is due to the sensitiveness here discovered that $I$ liave adopted the uniforn percentage of litınus, noted on page 218 . If litmus he added at the rate of 1 t per cent eoagulation preceded by bleaching takes place within 36 to 48 hours. Digestion then hegins and proceeds slighty more rapidly than in the milk, the contents of the tube varying in colour from a lemon sellow to claret with decided fluorescence in 72 hours. In 2 months digestion is not complete, 1-2 cm. of a jelly-like claret coloured curd remaining. 
SESSIONAL PAPER No. 38

If the quantity of litmus added be more than 11 per cent the reaction is quite different, varying aecording to the percentage of lituus added. There may or may not be coagulation, the colour varying from isabella to a muddy purpureus; flakes of tinted curl ean later be noted. In 2 montlis $n$ condition resembling broken jelly of a varicty of shades of purpureus lus berell recorded. A note referring to this phenomenon in greater detuil is being pubiished elsewhere.

Aesculin agar.-Growth moderute, Hat, dry. lirown to bluek.

Neutral Red Bile Salt Agar.-Cirowtl scant, no elaracteristie eolour reaciou.

Peptone Broth Aesculin.-Black in 12 hours.

Gelatine Colonies-(1st appearunee).-21 ${ }^{\circ} \mathrm{C} .4$ days, punctiform to pinherad colonies, depression in medium conunencing; under the low power objective strueture compact, finely gruuular, puler towards the edkes; edges cilinte.

Anar Colonies. $-37^{\circ}$ C. growth slow. 24 hours eolonies .5 mm. in dianeter, growth tends to be sulsurface. Inder the low power oljective enlonies round or eliptieal, edges entire to undulate, interual structure grauular, dark halo in surmunding medium.

Temperature Reinitions.--

Thermal death point. 10 minute' exposure in untricut broth at $60^{\circ} \mathrm{C}$.

Optimum temperature. $37^{\circ} \mathrm{C}$. ; cultures incolnuted at $37^{\circ} \mathrm{C}$., $21^{\circ} \mathrm{C}$. und $14^{\circ} \mathrm{C}$. respectively.

Vitality of Culture Media:-

Active cultures have been recorored from uyar tubes after 5 nontlis at temperature of $15^{\circ}-20^{\circ} \mathrm{C}$.

\section{Relation to Oxygen.}

Facultative annerobe. Tnder anurobie condition on gluerse ugur, growth visible in $24 \mathrm{hrs}$. at $37^{\circ} \mathrm{O}$.

\section{Biochemical Reactions:-}

Iudol produetion: no indol in $i$ days.

Reduetion of nitrntes: 10 reduetion to nitrites.

Voges-Proskauer renetion: negative.

Methsl red reaction: aeid to methyl red.

Fermentation of Carbohydrates:--

Glucose. Lactose. Succlarosc. Maltose. Mannite. I)uleite.

$$
\begin{aligned}
& \underset{\text { Dextrin. Saliein. Raffinose. Idonite. Inuliı. }}{+} \begin{array}{c}
+ \\
+
\end{array} \\
& \stackrel{+}{+} \text { Glyeerine. } \\
& t=\text { acill. } \\
& ++=\text { aceid and gus. }
\end{aligned}
$$

In uccordanee with the culturul results this orgunis. p properly included among the liquefying streptoeocei. Winslow ${ }^{14}$ takes the Str. gracilis of Fischerich. J.ehnnann and Nellmann as the "type eentre" of these liquefiers. Fe eonsiders that the various streptococei which peptonise gelatine more or less aetirely are variants of this type; intermedinte hetween it and some of those churacterized by Andrews and Horder ${ }^{35}$.

I fiud, however, a eloser resemblanee to un organism descrihed by MacCallum and

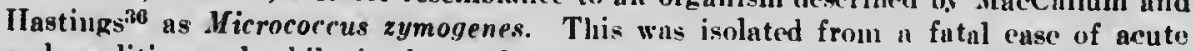
endocarditis, and while it shows the sane muiu charncteristic's as Str. yrarilis, it 
GEORCE $V, A .1018$

liquefes serum slightly and subsequent to congulating milk digest the clot. This organism was later found by Birge.37 It is in the two last characteristics that I find the close resemblance to $M$. symogenes noted aboze. The original description of Str. gracilis of Escherich eited by Winslow ${ }^{34}$ includes non-liquefaction of blood serum and failure to coagulate milk; but summing up the variations Winslow provisionally defines his "type centre" Str. gracilis as follows: Small coccus, appearing in chains, ferments lactose and coagulates milk, may ferment mannite and salicin. liquefies gelatine actively.

While the organiom I have described appears to have certuin particular characteristics, I hesitate to depart from Winslow's view regardiun the relationship of the variants in his tentative group of streptococeus liquefiers ${ }^{34}$. I conclude therefore that this organism which culturally and biochenically is identical with the $M$. zymo. genes of MacCallum and Hastings ${ }^{30}$ should be placed as a variety of the type Str. gracilis.

\section{SYMMARY AND CONCLUSIONS.}

1. Three strains of bacteria have been isolated from the destroyed tissue of copels which had died in culture flasks.

2. Summarized, the biologicnl features are as follows:-

\begin{tabular}{|c|c|c|c|}
\hline & 1. Fod-form. & II. Rod-form. & III. Coceun. \\
\hline 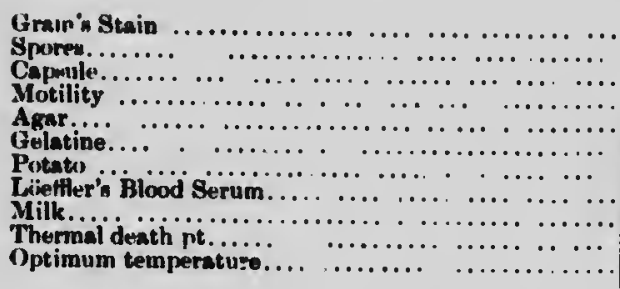 & 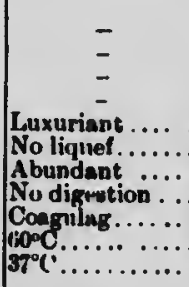 & 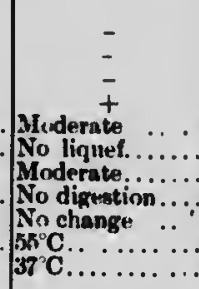 & 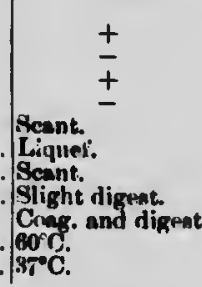 \\
\hline
\end{tabular}

3. Summarized, the biochemical ractions are:-

\begin{tabular}{|c|c|c|c|}
\hline-- & I. & II. & III. \\
\hline 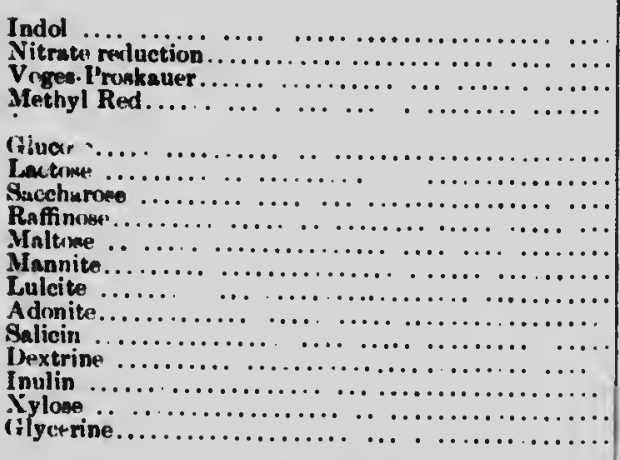 & $\begin{array}{l}+ \\
\pm \\
\text { Acid } \\
++ \\
+ \pm \\
++ \\
++ \\
++ \\
++ \\
++ \\
++ \\
++ \\
++ \\
+ \\
++\end{array}$ & 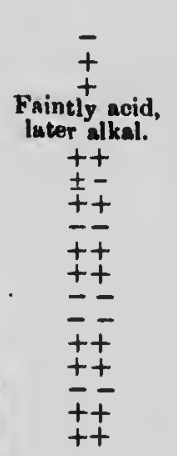 & $\begin{array}{c}- \\
\overline{-} \\
\text { Acirl. } \\
+ \\
+ \\
+ \\
\pm- \\
+ \\
\pm- \\
-- \\
+ \\
+ \\
\overline{+} \\
\overline{-} \\
--\end{array}$ \\
\hline
\end{tabular}

$t=$ ncid. $t+=$ acid and gas. 
SESBIONAL PAPER No. 38.

4. Based on their eultural featlres and biochenicul reactions the organiema are rlasoifled as follow: :-

Culture I.-Tentatively as a non-motile strain of the sub-type $B$. communior (Durham) of the type B. coli (Eecherieh); or to take the differentiation further, as $B$. meapolitanus, a sub-type of $B$. coli (Escherieh).

Culture II.-Considered tentatively as an atypieal form of the Para. Gaertner group after Savage.

Culture III.-Identieal with M. aymogenes and placed as a variety of the type of liquefying streptococei, Streptococcus yracilis.

6. No inoculations of these cultures have been made into healthy copepods owing to distance from the sea.

6. It is not legitimate to draw any definite conclusions regarding the relationslip of these orgauisms to the destruetion of the copepods, as no inoculation experiment have been earried out, and the postulates of Koch have not yet been satiefied. Aecording to the description presented, however, the evidence is strong in favour of Culture 11 I being a possible eausul agent.

I wish to thank very cordially Dr. F. C. Harrison for his kindness in reading the proofs, and particularly for his valuable and eritical assistanee with resard to the elassifieation of the $B$. coli group; and Dr. Arthur Willey for the initial suggestion that I should undertake the investigation.

\section{REFERENCES.}

1. Ameriean Public Health Association, 1915- "Standard Methods Winter Analysis," 77-137.

2. Bessoll, 1913-“"Text Book Practieal Buet., fte." (Longmans), 53.

3. Besson, 1913-“"Te:- 3ook Praetieal Buet., ete.," (Longmans), 52.

4. Harrison and Vanderleck, 1908-"Aesculin Bile Salt Agar for Water and Milk Analysis," Traus. Roy. Soe. Cau. III. Ser. II, 105-110.

5. Savage, 190 '- "Baeteriological Exnmination of Water Supplies," London, 2221.

6. Voges and Proskauer, 1898-"Zeit. fur IIyg." 28, 20.

6. Harden, 1905, 1906-“" On the Voges-Proskauer Reaetion for Certain Bacteria," Proe. Roy. Soc., 77, 424.

6. Ievine, Max., 1916-" "The Signifieance of tlee Voges-Proskaucr Reaetion," Jour. Baeteriology I, 153-164.

6. Clark and Lubs, 1915- "Differentiation of Bacteria of the Colon-Aerogenes Family by Indientors." Jour. Infectious Dis onses, 17, 100-173.

6. Levine-"Correlation of the Voge the Colon-Aerogenes group." Jour. Infec.

:oskauer and Methyl-red Renctions on

6. Levine-Private Communieation.

7. Clarke and Luls, 1915- "Differentiation of Bacteria of the Colon-Aerogenes Group." Jour. Infectious Diseases, 17, 160-173.

8. Bohme, 1905-Centrall. fur Bukt, Abt. I, Orig. XI, 129-13:.

9. MacConkey, 1909)-Jonrual of Hygiene, 9, p. 91.

8. Hollman, 1:14-“"Decolorized Acid Fuchwin as an Aeid Indieator in Curbolygdrate Fermentations." Journ. Infec. Dis., 15, 227-233. 
GEORGE V. A. 1918

10. Eacherich, 188ß- "Darmbak. drs Aaugliugn, Stuttgart,"

11. Migula 1884-" "System der Bakt," 390.

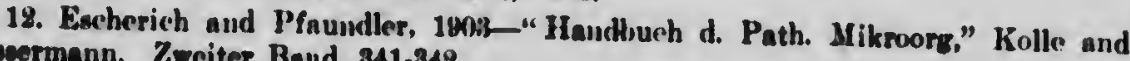
Wascermann. Zweiter Band, 841-342.

13. Sacherich und Pfaundler, 1903- - Haudbuch d. Path. Mikroorr." Kolle and Wassermaim. Zweiter Band, 406.

16. Houatou, 1905-"Bacteriological Bxamiunation of Milk." Special lleport, Iondou County Council, 37.

16. Durhan., Jouri. Fxp. Med., V., 354-388.

17. sacConkey, 1908_- "Lactose Femeuting Bacilli." Joum. Hygicue, 0, 88, 18. Ellis, 194-“ Dimonvery of Cilia in the genus Bacterium." Centrl. fur Bakt. II, 241-251.

10. 1904-" Report of the Kuulish Commission." Jour. State Med. XII, 471. 104.

20. 1913-Presioutt and Wiuslow. "Elements of Water Bacteriolony," Wiley,

21. Savuxe, 1906-" Bacteriolokical Fxamination of Water." Iewis, 82-843.

22. Migula, 1900-" Systenn der Bakterien," 734.

23. Emmerich, 1885- " Uutersuch. ub. die Pilze d. Cholera asiasticn." Arch. fur
Bd. 3. Hyk., Bd. 3.

Macé (full description) 1891- "Traitı Pratique de Bacteriologie." Paris, 498. 241.

24. Jackson, 1911-" Classification of the B. coli Group." Journ. Infec. Dis., 8,

25. Jordar, 1916-" General Bucteriology."” Saunder Co., 275.

25a. Lon. cit.. 273.

26. Leviue, 1910-“ "Jrelininary Note, ('lassifiention of the Lactose Fermenting Bacteria." Journ. Bacteriology, I., B19-621. 3:33-370.

27. MacConkey, 1905.- - Lactose fermentiug Bacteria in Fueces." Jouru. Hyg. 5,

28. Harrison, 1917-Private communicution.

29. Jordan, 1890- "Report Mass. State Bonrd of Health." 836.

30. Rogers Clarke \& Evans, 1915-"Charact. of Racteria of Colom type oecurring on Grains," Journ. Infec. Jis., 117, 137-159.

31. Besson, 1913-“"Text Book Practicul Bacteriology, ete.” Longmans, 442.

32. Jordan, 1917-“ "Differentiation of the Puratyphoid-Enteritides Group." Journ. Infect. Diseasen, 20, $45 \%$.

33. Savage, 191:-“ Bacterinl Food Poismink and Food Infection." Med. Off.

Report, Local (iovt. Board, 1913. Food Reports, No. 18, 33.

34. Winslow, C.-F. A. and A. R., 1908-" The Systematic Relationship of the Coeeacen ค." Wiley. New York, 161, 169, 170.

35. Andrews d Iforder, 1906-" A Study of the Streptoeocei pathogenic for Man."

36. MacCallum, W. (i. \& Jastings. T. W., 189!-" $\Lambda$ case of Acute Endoearditis caused by M. Zymogenes." Jouru. Exp. Med. TV.. 521.

37. Birge. 1905.

37. Birge, 1905-"Sonne Gbservations ou the Oreurrence of M. Z.rmogenes." Johus Iopkins Hosp. Bull. XVI., 309.

38. Escherich Migula, 1900-"System der Bakterieu," 31. 


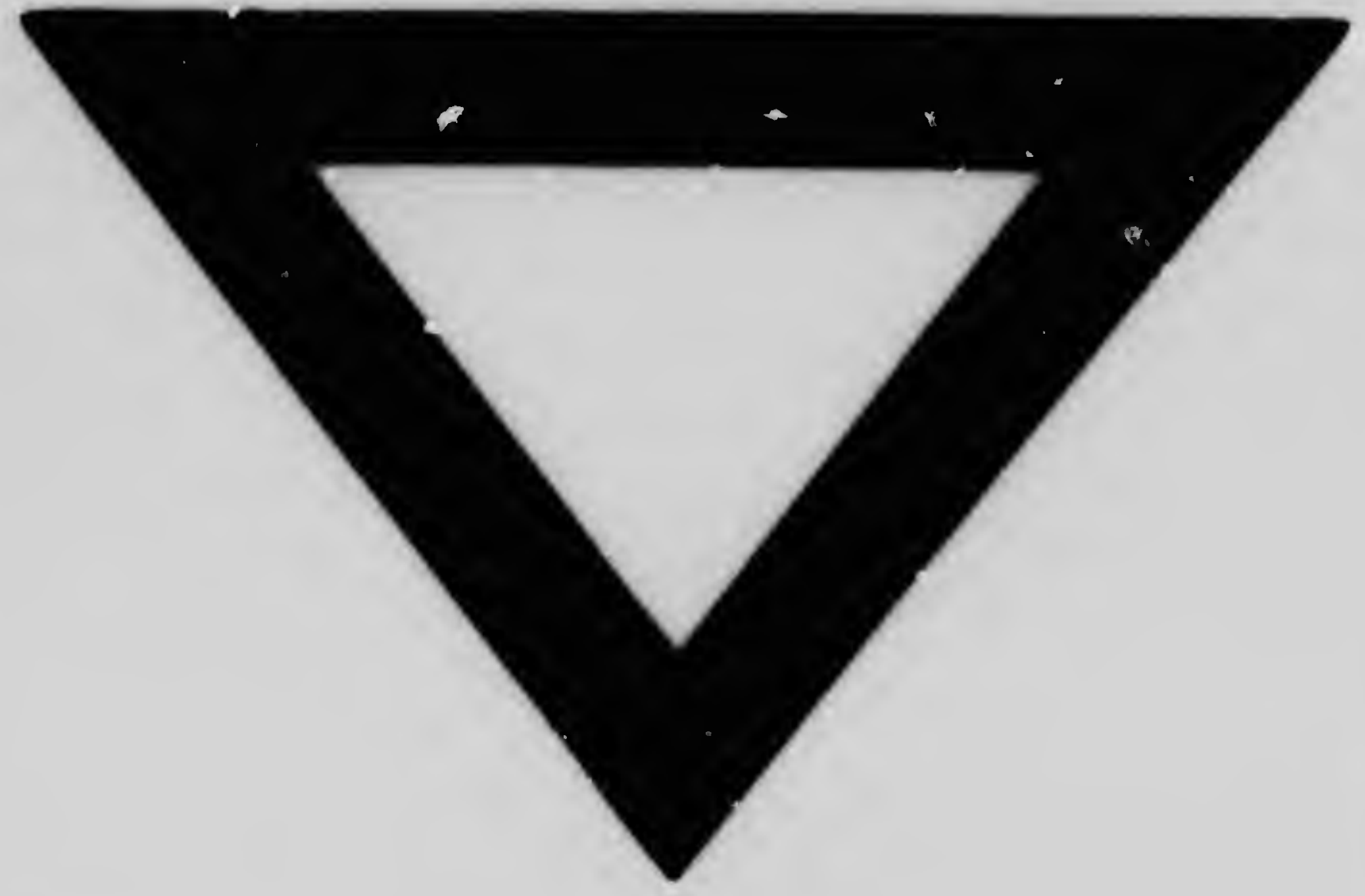

